\title{
DO WE NEED TO REBUILDING CHARACTER ?
}

\author{
Citra Ayudiati ${ }^{1}$, Endarwati ${ }^{2}$ \\ 1,2 Akuntansi Universitas Cokroaminoto Yogyakarta \\ ${ }^{1,2} \mathrm{Jl}$. Perintis Kemerdekaan, Gambiran, Pandeyan, Umbulharjo, Kota Yogyakarta 55161 \\ ${ }^{1}$ Email: citra@ucy.ac.id \\ ${ }^{2}$ Email: endarwati@ucy.ac.id
}

\begin{abstract}
ABSTRAK
Perkembangan pendidikan di Indonesia telah berkembangan dengan sangat pesat, tidakhanya perkembangan ilmu pengetahuan namun juga perkembangan teknologi informasi telah membawa perubahan yang sangat besar dalam pola pendidikan di Indonesia. Pendidikan adalah sebuah gerbang yang akan membawa mahasiswa menjadi generasi penerus bangsa ini, tidahk hanya sekedar membangun bangsa namun juga membangun karakter bangsa supaya bangsa ini menjadi bangsa yang besar. Pendidikan karakter bisa terinternalisasi dalam kurikulum yang nantinya akan membantu mahasiswa mengembangkan karakter diri. Penelitian ini mengambarkan sejauh mana pendidikan karakter akan membantu mahasiswa dalam mengembangkan dirinya. Hasil penelitian ini adanya keterlibatan pendidikan karakter dalam kurikulum akan membantu mahasiswa menghadapi dunia pekerjaan yang akan dipengaruhi oleh karakter yang dibangun dari sejak memulai pendidikan atau bisa ditumbuhkembagkan bahkan pada saat perkuliahan. Keseuaian antara mahasiswa dan dosen akan membantu juga dalam pengembangan pendidikan karakter.
\end{abstract}

Kata Kunci: Pendidikan karakter, penumbuhan, pengembangan.

\section{PENDAHULUAN}

Dalam era yang semua beralih pada digitalisasi , tantangan terbesar bangsa Indonesia ternyata tidak terletak pada pegembangan Teknologi informasi namun terletak pada mentalitas masyarakat kita, dimana adanya digitalisai atas Tehnologi Informasi juga menyebabkan banyak masalah sosial. Bangsa yang diberkahi oleh Alam yang melimpah dengan berbagai sumber daya alam yang ada didalamnya, geografis negaranya yang begitu berwarna warni ibarat surga dunia Indonesia menjadi perhatian dunia, namun perhatian itu tidak hanya pada kekayaan sumber daya alamnya saja namun perhatian yang lain juga . Dalam perkembangan negara Indonesia para pemimpin negara ini banyak mendapat sorotan dari berbagai negara. BUkan sorotan yang baik, namun lebih pada ketidak mampuan negara hadir bagi seluruh rakyatnya. Banyaknya kasus korupsi yang merugikan negara menjadi salah satu indicator ada yang salah dengan negara ini. Lihatnya betapa banyak warga miskin yang tidak bisa mendapatkan kesejahteraan.

Korupsi menjadi salah satu penyakit menular yang menjadi momok bagi bangsa ini, yanglebih menyedihkan lagi adalah banyaknya pejabat negara yang terlibat dalam berbagai korupsi yang merugikan negara bisa mencapai milyaran bahkan trilyunan rupiah. Apakah ada contoh pemimpin yang baik dalam pemerintahan yang penuh dengan korupsi. Berbagai pertanyaan timbul atas berbagai kasus korupsi yang timbul di Indonesia, Apakah sudah menjadi keumuman atau bahkan menjadi karakter bangsa ini? Pertanyaan yang begitu menyakitkan dunia Pendidikan, karena 
bagaimanapun Ilmu itu digunakan untuk membentuk manusia lebih bermoral, beradab dan memiliki etika, namun mengapa masih banyak kasus korupsi yang terjadi bahkan bisa menular.

Berdasarkan fakta yang ada di lapangan, lingkaran korupsi itu tidak hanya bertumpu pada satu tempat namun telah menjadi jaringan yang terikat sehingga rantainya akan sulit di putuskan. Contohnya: korupsi terjadi jika para pejabatnya korup, penegak hukumnya juag terlibat. Proses hukumnya bermasalah, rakyat tidak memiliki kepercayaan kepada pemimpinnya, rakyatnya tidak prosuktif, karyawan melakukan kecurangan di kantor, masyaarakat tidak memiliki empati, mahasiswa tidak memiliki figur yang digunakan sebagai role model untuk beralih ke dunia nyata dari dunia Pendidikan. Semua permasalahan ini kembali kepada moralitas manusianya.

Dalam dunia Pendidikan mahasiswa mendapatkan berbagai ilmu yang akan digunakan untuk berkembang didalam dunia kerja. Pendidikan merupakan sebuah gerbang yang akan mengantarkan mahasiswa melangkah menuju dunia nyata yang akan sangat berbeda dengan dunia Pendidikan. Sepanjang sejarah dunia Pendidikan telah memiliki tujuan yaitu menjadi cerdas dan pintar (smart) dan membantu mereka menjadi manusia yang baik (good). (Sudrajat, 2011).

Dalam dunia Pendidikan salah satunya sebagai contoh dalam Perguruan Tinggi dalam hal ini kami mengamati dalam program studi Akuntansi dimana para "Calon Akuntan" yang nantinya akan melakukan pencatatan, perhitungan, pelaporan bahkan melakukan evaluasi audit dimana dalam setiap pekerjaan memerlukan pertanggungjawaban diriyang sangat tinggi. Pernahkah kita mendengar peribahas "Karena Nila Setitik, rusak susu sebelangga". Dalam dunia akuntansi atau keuangan secara umum, para "Calon Akuntan" ini memili peranan yang sangat besar bagi perkembangan keuangan di begara ini baik dalam sector swasta maupun di sector publik.

Masih ingatkah kita akan kasus Gayus Tambunan dan Dhana Widyatmika serta banyak kasus pelanggaran oleh perusahaan public untuk mendapatkan Wajar Tanpa Pengecualian (WTP) dari akuntan public. (Yusdita, 2014). Kemudian kaitan dengan korupsi dimana KPK menunjukkan 658 perkara dalam rentang 2004 - 2014, dimana penyimpangan ini seolah menjadi antiklimaks dimana banyak orang orang yenga beranggapan anti mainstream dimana spernyataan " Sekarang semua tidak ada yang tidak dikorupsi” yang melahirkan persepsi bahwa korupsi adalah budaya yang baru yang wajar bila diikuti. Namun dalam dunia Pendidikan terutama Perguruan Tinggi kita diajarkan bahwa setiap profesi memiliki etika profesi dimana banyak yang memberikan pelajaran tersebut dalam dunia Pendidikan yang disesuaikan dengan keahlian masing masing. Dalam dunia Pendidikan akuntansi kita amenngenal adanya Etika Profesi Akuntan yang dipelajari oleh semua mahasiswa Akuntansi.

Tentunya kita semua mengetahui bahwa kode etik dibuat untuk mengatur agar tidak bertindak semaunya tanpa memperhatikan nilai nilai moral yang merupakan bagian dari nilai nilai kode etik. 
Banyak pertanyaan yang akhirnya muncul, apakah kode etik ini bisa dimplementasikan dengan baik? Apakah tanpa kode etik profesi akuntan misalnya tidak beretika?

Menurunnya nilai moralitas ini berdampak pada karakter manusia dimana karakter sesorang itu akan membentuk sikap indivisu dalam berorganisasi, bersosial bahkan merasakan empati. Oleh karena itu Pendidikan tinggi menjadi sebuat kawah untuk membentuk karakter pribadi sebagai penerus bangsa ini. Pendidikan karakter diarahkan untuk memberikan tekanan pada nilai nilai tertentu seperti rasa hormat, tanggung jawab, jujur, peduli dan adil dan membantu siswa untuk memehami, mempeerhatikan dan melakukan nilai nilai tersebut dalam kehidupan mereka sendiri. (Sudrajat, 2011). Pendidikan karakter di Inodnesia telah dicanangkan dalam setiap tahun pembelajaran dari semua jenjang dari Tk sampai dengan PT. Namun berbagai permssalahan yang timbul telah menjadi pertanyaan "Apakah kita memerlukan pembangunan ulang Pendidikan Karakter" (Do We Need to Rebuilding Character?). Fenomena yang terjadi akan sangat menarik untuk dianalisa dan diteliti sehingga bisa menghasilakn sebuah kajian yang bisa mengatasi masalah Pendidikan karakter terutama di wilayah mahasiswa dalam konteks Pendidikan Tinggi.

\section{KAJIAN TEORI}

Fungsi dan Tujuan Pendidikan

Fungsi dan tujuan Pendidikan bisa kita lihat dari sudut pandang atau perspektif yang secara umum menurut Undag Undag RI tahun 2003 .(Juanda \& Sofyani, 2016) Menurut Undang-Undang RI tahun 2003 tentang sistem pendidikan nasional, dideskripsikan bahwa fungsi pendidikan adalah untuk mengembangkan kemam- puan dan membentuk watak serta peradaban bangsa yang bermartabat dalam rangka mencerdaskan kehidupan bangsa. Dari beberapa pandangan ten- tang fungsi pendidikan secara umum adalah bahwa ada dua fungsi yang paling mendasar, yaitu peningkatan kualitas pribadi dan kualitas sosial. Pening- katan kualitas pribadi menyangkut kemampuan intelektual, ketrampilan, kepribadian dan lain-lain. Kualitas sosial menyangkut integrasi sosial, transmisi dan lain-lain. Kualitas sosial menyangkut integrasi sosial, transmisi kebudayaan dan mutu kehidupan.

\section{Pengertian Karakter}

Karakter dalam asal katanya berasal dari Bahasa Yunani Charasssein yang dapat diartikan to engrave (melukis, menggambar) sepertimelukis, memahat. Melihat pengertian maka character dapat kita artikan sebagai tanda atau ciri yang khusus yang leahirkan pandangan pad pola perilaku yang bersifat individu, keadaan moral seseorang. Setelah melewatu tahao anak anak maka sesorang memiliki karakter Karakter yang baik berkaitan dengan mengetahui yang baik (knowing the good), 
mencintai yang baik (loving the good), dan melakukan yang baik (acting the good). Ketiga ideal ini satu sama lain sangat berkaitan. Seseorang lahir dalam keadaan bodoh, dorongan-dorongan primitif yang ada dalam dirinya kemungkinan dapat memerintahkan atau menguasai akal sehatnya. Maka, efek yang mengiringi pola pengasuhan dan pendidikan seseorang akan dapat mengarahkan kecenderungan, perasaan, dan nafsu besar menjadi beriringan secara harmoni atas bimbingan akal dan juga ajaran agama.

Alasan perlunya Pendidikan karakter

Menurut Lickona (Sudrajat, 2011)ada tujuh alasan mengapa pendidikan karakter harus disampaikan yaitu :

1. Cara terbaik untuk seseorang memiliki kepribadian yang baik dalam kehidupannya.

2. Pendidikan karakter adalah salah satu cara untuk meningkatkan prestasi akademik.

3. Lembaga Pendidikan menjadi tempat yang kondusif untuk membentuk karakter siswa.

4. Pendidikan karakter sangat membantu untuk meradaptasi dengan kehidupan sosial.

5. Karakter dapat membantu mengatasi masalah masalah sosial.

6. Pendidikan karakter dapat membantu mempersiapkan diri dalam menyambut dunia kerja dengan perilaku yang baik.

7. Pembelajaran nilai nilai budaya dari kerja peradaban.

Nilai

Nilai adalah sebuah prinsip umum yang menyediakan anggota masyaraat untuk memilki standar ukuran untuk membuat penilaian atau pemilihan mengenai Tindakan dan cita cita tertentu. Dimana nilai adalah konsep, suatu pembentukan mental yang dirumuskan dari tinngkah laku manusia. Nilai adalah perssepsi yang sangat penting, baik dan dihargai. Menurut Clyde Kluckhlon (1953) dalam (Mustari, 2011) nilai adalah standard yang waktunya agak langgeng. Nilai juga bisa dikatakan sebagai keutamaam (preference) uaitu sesuai yang lebih disukai, baik mengenai hubungan sosial maupun mengenai cita cita serta usaha untuk mencapainya, nilai melibatkan unsur komitmen.

Penumbuhan Karakter

Runtuhnya karakter bisa diperbaiki dengan menghilangkan karakter yang tidak baik atau memperbaiki factor factor yang menyebabkan buruknya karakter. Karakter yang baik dalam ranah Pendidikan bisa dibentuk melalui:

a. Keluarga

b. Pribadi 
c. Pemerintah

d. Sekolah

e. Lingkungan dan masyarakat

\section{Penumbuhan Kembali}

Menumbuhkan kembali nilai niali yangakan membentuk karakter, bentuk pengingat bahwa karakter sesorang akan meberikan konsekuensi dalam kehisupan seseorang. Karakter yang baik akanmemberikan nilai nilai hisup yang positif dan membnatu menyangga kembali kehidupan dan peradapan manusia, ada beberapa nilai nilai dalam kehidupan manusia yang bisa kita jadikan sebagai acuan pendiidkan karakter diantaranya adalah:

Religius , Jujur, bertanggung jawab, bergaya hidup sehat, disiplin, kerja keras, percaya diri, berjiwa wirausaha,berpikir logis, kreatif dan inovatif, mandiri, ingin tahu,cinta ilmu, sadar diri, patuh sosial, respek, santun,demokratis,,nasionalis.

Dalam Pendidikan akuntansi ada nilai niali khusus yang akan membentuk karakter yang positif dimana apabila dijaga dengan baik akan menjadi keuanggulan tersendiei didalam lingkungan bisnis dan masyarakat secara luas. Dalam dunia akuntansi nilai yang tertinggi adalah akuntabilitas dimana diartikan bisa dipertanggungjawabkan. Setiap angka yang tercantum dalam laporan akuntasi harus dapat dipertanggungjawabkan atau akuntabel.

Untuk mempertanggungjawabakan laporan maka diperlukan karakter karakter khusus yang harus dimiliki oleh lulusan Akuntansi supaya bisa menjadi akuntan yang handal yaitu:

\section{Akurat}

Dalam akuntansi keakuratan menjadi bagain yang sangat penting dikarenakan akuntansi sangat erat kaitannya perhitungan. Tuntutan karakter akurat ini akan menimbulkan trust (kepecayaan) dari pihak lain baik dalam lingkungan bisnis atau lingkungansosial

\section{Detail}
Akurasi membutuhkan detail.Tanpa detail yang cukup, akurasi tidakakan tercapai. Setiap pekerjaan akuntansi yang manapun, selalu detail. Attenion of detail menjadi salah satu karakter yang diutuhkan.

\section{Logis}

Dalam memahami pekerjaan membutuhkan ilmu logis dikarenakan akuntansi bukanlah ilmu exacta. Logis adalah nilai positive dalam dimensi kehidupan manapun, baik dalam lingkungan bisnis maupun sosial masyarakat. 
4. Terukur

Logika yang bisa didcerna adalah logika yang terukur sehingga logika yang terukur adalah harus logi dan terukur. Dalam lingkungannya logika terukur sselalu menggunakan rujukan pasti baik dalam hukum, norma, etika, budaya dan nilai nilai agama yang berlaku di lingkungannya.

5. Konsisten

Akuntabilitas, disamping butuh akurasi, detail, kelogisan dan keterukuran juga membutuhkan konsisten.

6. Disiplin

Kedispilinan dalam karakter yang akan dibutuhkan adalah:

a. Tidak menyepelekan fakta (data) sekecil apapun

b. Taat pada prosedur dan kebijakan perusahaan

c. Taat pada aturan pemerintah

d. Taat pada standard kode etik

e. Taat pada prinsip yang berterima umum dan praktek yang lazim.

\section{Skeptis}

Skeptip dalam hal ini adalah karakter yang positif dimana dapat diartikan untuk tidak mudah mengatakan iya dan tidak mempercayai informasi sebelum melakukan verifikasi.

8. Sederhana

Karakter kesederhanaan dalam akuntansi lebih pada kehati hatian dalam melakukan proses akuntansi.

9. Jujur

Kejujuran adalah hal yang paling penting dalam hal akurasi, detail, kelogisan, keterukuran, konsistensi dan lain lainnya.

10. Gigih

Kegigihan, kemauan dan daya juang yang tinggi adalah niai positiv dimanapun maka itulah syarat mutlak.

\section{METODE PENELITIAN}

Penelitian ini termasuk dalam pendekatan penelitian pada studi kasus. Dimana Herdiansyah menyatakan bahwa penelitian kualitatif adalah penelitian yang bermaksud memahami fenomena tentang apa yangterjadi di lapangan serta mendeskripsikan dalam bentuk kata kata dan Bahasa. Penelitian kualitatif yang dilandasi untuk memahami fenomena sosial dan memiliki focus untuk mendalami alasan suatu tindakan sosial baik dari segi etika, pola pikir, rasionalitas dan nilai 
budaya. (Dhamar Yudho Aji onesia, 2008). Penelitian ini menggunakan sstudi kasus yang digunakan untuk menerapkan beberapa alassan. Objek penelitian ini adalah mahasiswa Akuntansi yang akan menjalani siding skrispi. Terpilihlah 5 mahasiswa yang akan melakukan siding skrispi. Peneliti akan memberikan pertanyaan degan menggunakan metode wawancara untuk melihat sejauh mana karakter yang dipelajari oleh mahahsiswa yang bersangkutan. Penelitia akan menanyakan pendapat mereka tentag karakter calon akuntan dan hubungannya dengan kasus kasus yang berkaitan dengan etika profesi.

Teknik pengumpulan data adalah studi pustaka, wawancara, observasi dan juga dokumentasi. Pertanyaan yang diajukan mengenai pemahaman atas konsep akuntansi dan kaintannya dengan pemahaman karakter seorang calon akuntan.

Penelitaian ini menggunakan analisis deskriptif kualitatif, yaitu analisis data yang dilakukan secara beriringan dan simultan. Tahapan dalam penelitian ini adalah mengumpulkan dan Menyusun hasil studi Pustaka, mengumpulkan data data yang diperlukan dan bberkaitan dengan objek yang akan diteliti.

\section{PEMBAHASAN}

Sejauh mana pola Pendidikan kita bisa membantu mahasiswa membentuk karakter diriyang baik dan sesua dengan kebutuhan lingkugan bisnisnya. (Yusdita, 2014)Tingkat motivasi sesorang dalam menyelesaiakan kewajibannya menurut Kant ada beberapa tingkatan motivasi yaitu:

1. Sesorang melaksanakan kewajibannya karena dengan mengerjakannya ia mendapat keuntungan atau manfaat tertentu

2. Seseorang melaksanakan kewajibannya karena apa yang ia rasakan, misalnya terdorong atas rasa takut.

3. Seseorang melaksanakan kewajibannya karena keinginannya sendiri, yang kita namakan sebagai Moralitas.

Weiss dalam (Yusdita, 2014) menyebutkan beberapa tingkatan kematangan moral sesorang menurut pandagan pengmebnagan moal Kohlberg, yaitu sebagai berikut :

1. Tingkat Prakonvesnional (orientasi pada diri sendiri) yang terdiri dari :

a. Tahap 1: Jika sseseorang melakukan sesuatu untukmenghindari hukuman, maka orang tersebut memiliki ssedikit kepedulain akan orang lain

b. Tahap 2 : Jika seseorang melakukan sesuatu untuk mencari penghargaan atau hadiah, maka orang tersebut memiliki kepedulian akan orang lain , namun bukan benar/salah dalam konsep abstrak 
2. Tingkat Konvensional (berdasarkan orientasi lainnya) yang terbagi menjadi beberapa tingkatan yaitu:

a. Jika seseorang ingin menjadi "orang baik" dan diterima oleh komunitasnya dengan bertindak benar, maka orang tersebut dapat dikatakan bukan untuk memenuhi suatu moral yang ideal.

b. Jika sesorang bertindak benra karena memetuhi hukum dan norma yang berlaku

3. Tingkat pascakonvesional (memiliki orientasi kemanusiaan) yang terdiri dari :

a. Jika seseorang bertindak benar untuk mencapai kesepakatan tertentu, maka orang tersebut menyadari relativitas nilai danmenyadari keberagaman paradigma

b. Jika seseorang bertindak benar berdasarkan prinsio keadilan dan hak, maka orang tersebut bertindak sesuai hati Nurani dan moral.

Pendidikan karakter di lingkungan program studi akuntansi dalam hal ini adalah menilai dari kurikulum yang digunakan dan juga model pembeelajaran yang ada. Dalam penelitian kami memberikan beberapa pertanyaan yang berkaitan dengan kassus yang terjad dan menilai bagaimana tanggapan mahasisiwa terhadap kassus tersebut.

Kasus yang kami tanyakan adalah kasus yangberkaitan dengan kassus Gayus Tambunan, ada 4 kasus yan menjerat Gayus Tambunan yaitu:

1. Kasus penyuapan hakim PN dan penggelapan pajak PT. Surya Alam Tunggal

2. Kasus pemalsuan paspor ke luar negeri

3. Kasus penggelapan pajak PT Megah Citra Raya

4. Kasus gabungan 3 kasus diatas

Kami memberikan data data dari media yang berkaitan dengan kasus tersebut dan kami meminta mahasiswa untuk memberikan analisanya dan alasannya mengapa memberikan Analisa tersebut. Dan kami kaitkan gasil dari mahasisiwa dengan pemndidikan karakter dan juga penumbuhan karakter. Hasil dari jawaban mahasiswa kami rangkum dalam bentuk Analisa seacara garis besar dan menggambarkan bagaimana mahasiswa memberikan analisanya.

Analisa kasus kita mulai dari karakter dasar yang harus dimiliki calon akuntan atau yang berkaitan dengan pekerjaan keuangan. Dalam hal religiussitas apa yang dilakukan oleh Gayus Tambunan telah melanggar nilai nilai agama dimana yang dilakukan adalah perbuatan curang yang menyebabkan kerugian negara dalam jumlah yang besar. Dalam hal ini Pendidikan anti korupsi dapat di masukkan dalam hal hal yang berkaitan dengan nilai nilai agama yang lebih mengena dan lebih berkarakter. Dalam hal pembelajaran Pendidikan morak sangatlah penting dalam mengantar dan membimbing unutk beranjak pada fase berikutnya. Dalam konteks ini, jika satuan pembelajaran yang berkarakter dipahami sebagai sebuah proses perkembangan terus- menerus 
seorang individu dalam menyempurnakan keberadaan dirinya sebagai makhluk yang bermoral, setiap kegiatan edukatif yang bermanfaat bagi per-kembangan kehidupan moralnya sangatlah relevan bagi dirinya.

Untuk itu, kaum dewasa pun masih tetap membutuhkan sebuah satuan pembelajaran berkarakter khas. Satuan pembelajaran ini bukanlah sebuah aset yang bisa otomatis dimiliki, melainkan sebuah kemungkinan yang terbuka di mana setiap individu merangkai, membangun, dan membentuk karakter individualnya sesuai dengan kemungkinan yang terbuka di hadapannya secara dinamis.

Satuan pembelajara yang berkarakter dipakau juga untuk mengacu pada penngetahuan yangberkaitan dengan Pendidikan, teori dan aplikasi. Dalam pembahasan wawancara juga para mahasiswa juga manyatakan bahwa unsur tidak mensyukuri nikmat yang diberikan oleh Tuhan kepada kita. Kasus Gayus Tambunan yang notebene sudah bekerja di kantor Pajak dengan penhasilan yang sudah besar. Namun perlu juga kit aperhatikan latar belakang kehidupan sosial mereka. Salah satu yang bisa dijadikan pelajaran dalam kehisupan mahasiswa adalah mengukuhkan nilai nilai positif humanisttik. Untuk memulai maka kita bisa pembelajaran anti korupsi seperti:

1. Mengembangkan dan menumbuhkan nilai positif manusia, seperti suka menolong, berbuat baik, beriman dan bertaqwa.

2. Mengajarkan pesan moral kepada manusia, terutama pemimpin, agar berbuat yang sesuai dengan harapan masyarakat, mencintai keadilan, kebenaran dan kejujuran.

3. Mendorong orang untuk bekerja keras demi kepentingan dirinya dan kepentingan Bersama.

4. Memperkukuh dan menumbuhkembangkan karakter pribadi, identitas dan ketahan bangsa yang positif, Tangguh dan kuat demi mencapai cita cita bangsa dan negara.

Upaya untuk menguatkan identitas dan ketahanan bangsa terhadap kejahatan yang berlabel korupsi, sebaiknya dilakukan upaya preventif sedini mingkin, yaitu sejak dini. Namun tidak ada kata terlambat untuk memulai untuk menumbuhkan karakter yang baik dengan kehidupan kampus dan pembelajaran yang sesuai dengan kebutuhan masing masing program studi. Dalam dunia Pendidikan, peran serta pendidik atau di kalangan Pendidikan tinggi ada Dosen yang bertindak sebagai Pendidik. Dosen, Dosen harus mampu menghadirkan bentu bentuk karakter yang terinternalisasi ke dalam berbagai mata kuliah yang nantinya akan membentu karakter yang sesuai dengan etika pada program studi masing masing. (Kamayanti, 2012).

Pengembangan kurikulum berbasis karakter yang bisa dimodifikassi dalam program studi akuntansi dimana ada berapa mat akuliah yang bisa dimasukkan epndiidkan karakter seperti 
Akuntansi Keuangan, Auditing dan lain sebagainya. . Dimana kita menggunakan startegi untuk mengembangkan karakter peserta didik:

1. Pendidikan Tinggi sebagai Inner Capacity unutk memberi pengetahuan karaktaer mengenai Moral Knowing, Moral Feeling dan Moral action.

2. Pendekatan penanaman nilai, perkembangan, analisis nilai, pembeljarana dalam bentuk dialog, diskusi, problem solving dan berbagai pengalaman dan penemuan.

3. Menetapkan kurikulum untuk kurikulum yang berkesinambungan dan hlistik dan perlu adanya sinkronisasi yang seimbang antara Perguruan Tinggi dan stakeholders

4. Pembentukan karakter juga membutuhkan teladan dan contoh yang akan memudahkan mahasiswa untuk memahamipenerapannya

5. Inherent dengan mata kuliah seperti adanya studi kasus untuk mengetahui kesalahan kesalahan dalam kasus yang akan berpengaruh pada karakter mahasiswa.

6. System evaluasi untuk mengethaui apaka Pendidikan karakter telah ada dalam kurikulum dan lingkungan perguruan tinggi kita.

Ketika semua Pendidikan karakter telah ditumbuhkan maka Pendidikan karakter dalam lingkungan kampus maka mahasiswa akan mempunyai karakter yang kuat yang sesuai dengan kebutuhan pada masing massing keahlian.

\section{SIMPULAN}

Berdasarkan pembahasan diatas maka dapat kita simpulkan bahwa pembangunan karakter sangatlah diperlukan bagi generasi yang lebih baik dimasa depan. Perkembangan dunia pendidikan dan dunia pekerjaan akan sangat berdampak pada karakter sesorang. Bagi peneliti menempatkan religiusitas menjadi pilar utama pembentuk karakter sesorang akan memberikand ampak positif yang membangun karakter seseorang. Nilai nilai karakter yang ada seperti kejujuran, kerja keras, empati, gigih dan sebagainya yang akan membnatu membentuk karakter akan lebih memiliki peranan dan penguatan yang sangat kuat jika pondasi religiusitas dapat di terapkan dengan baik.

Penetapan kurikulum berbasis karakter akan membantu mahasiswa untuk menyiapkan diri dalam menghadapi dunia nyata. Internalisasi dalam kurikulum tidak hanya menyediakan mata kuliah yang sesuai dengan pembangunan karakter. Adanya kesesuaian hubungan antara dosen dengan mahasiswa dalam menerapkan knseo Pendidikan karakter. Mendalami semua ini dapat kita pastikan bahwa pendidikan dan penngambunan karakter akan sangat membantu dalam pengembangan karakter mahasiswa. 


\section{SARAN}

Penelitian ini masih terdapat banyak terdapat kekurangan, kajian kajian yang lebih mendalam sangat diperlukan untuk membuat konsep pendidikan karakter lebih bisa dikembangkan yang nantinya akan membawa perubahan yang besar bagi karakter mahasiswa.

\section{DAFTAR PUSTAKA}

Dhamar Yudho Aji onesia, dan A. F. M. (2008). Persepsi Etis Mahasiswa Akuntan Atas Praktik Akuntansi Kreatif. Cell, 151(4), 1-46. https://doi.org/10.1016/j.cell.2009.01.043

Juanda, J., \& Sofyani, H. (2016). Konsep Pendidikan Karakter Keagamaan Untuk Calon Akuntan: Studi Kasus di Program Studi Akuntansi Universitas Muhammadiyah Yogyakarta. Jurnal Akuntansi Dan Investasi, 17(2), 186-196. https://doi.org/10.18196/jai.2016.0054.186-196

Kamayanti, A. (2012). Cinta: Tindakan Berkesadaran Akuntan (Pendekatan Dialogis Dalam Pendidikan Akuntansi). Simposium Nasional Akuntansi XV Banjarmasin 2012, April 2012, $1-30$.

Mustari, M. (2011). Refleksi Untuk Pendidikan Karakter. 1-13.

Sudrajat, A. (2011). Mengapa Pendidikan Karakter. 1(1), 47-58. https://doi.org/10.21831/jpk.v1i1.1316

Yusdita, E. E. (2014). Pendebetan etika dalam jiwa akuntan Indonesia: pemupukan nilai pancasila oleh pendidik. Media Mahardika, 12(3), 28-40. 